\title{
Comparative Studies of the Phytochemical and Antioxidant activities of the leaves, stems, roots, and seeds extracts of Mitracarpus scaber Zucc (Rubiaceae)
}

\author{
Bea Gouanda Thibaut ${ }^{1,3}$, Coulibaly Wacothon Karime ${ }^{2, *}$, Benie Anoubilé ${ }^{1}$, Kablan Ahmont Landry \\ Claude $^{2}$, James Tembei Titah ${ }^{4}$, N'Guessan Hugues Alain ${ }^{1}$, Kabran Aka Faustin ${ }^{3}$, Konan Dibi Jacques ${ }^{3}$, \\ and Attioua Koffi Barthélemy ${ }^{3}$ \\ ${ }^{1}$ Laboratoire de Chimie Bio-Organique et de Substances Naturelles, Université Nangui Abrogoua, Abidjan, \\ Côte d'Ivoire \\ ${ }^{2}$ UPR de chimie organique, Département de Mathématiques, Physique et Chimie, UFR des Sciences \\ Biologiques, Université Peleforo Gon Coulibaly, Korhogo, Côte d'Ivoire \\ ${ }^{3}$ Laboratoire de Constitution et Réaction de la Matière, UFR Sciences des Structures de la Matière et \\ Technologie, Université Félix Houphouët-Boigny, 22 BP 582 Abidjan 22, Côte d'Ivoire \\ ${ }^{4}$ Tabor College, Department of Chemistry-Science \& Mathematics, Hillsboro, KS, USA
}

\begin{abstract}
Extracts of the leaves, stem, roots, and seeds of Mitracarpus scaber plants have been thoroughly investigated in an attempt to determine their phytochemical and antioxidant activities. Phytochemical screening carried out by thin-layer chromatography (TLC) revealed the presence of several secondary metabolites in all the selective extracts of the plant. The levels of phenolic compounds showed that the leaves of M. Scaber are the richest in polyphenols with an average value of $488.291 \pm 1.205 \mu \mathrm{g} \mathrm{GAE} / \mathrm{g}$ (microgram of gallic acid equivalent per gram of the dry matter of the powdered plant). The total flavonoid assay revealed a high content in the leaves $(1.624 \pm 0.032 \%)$. Also, studies of the antioxidant activities by DPPH ${ }^{\bullet}$ (2,2-diphenyl-1'-picrylhydrazyl) method showed a significant effect compared to vitamin C $(96.62 \%)$. The percentages of inhibition are respectively $89.82 \%$ and $82.3 \%$ for ethyl acetate extracts of the leaves and seeds. Furthermore, the inhibitory percentages of n-butanol in the leaves and seeds are $90.57 \%$ and $83.67 \%$, respectively. Calculated IC $_{50}$ showed that the nbutanol fraction of the seeds exhibited the highest activity with an $\mathrm{IC}_{50}$ of $0.293 \mathrm{mg} / \mathrm{mL}$ less than ascorbic acid with an $\mathrm{IC}_{50}$ of $0.387 \mathrm{mg} / \mathrm{mL}$.
\end{abstract}

Keywords: Rubiaceae; Mitracarpus; Phytochemical; Polyphenols; Antioxidant.

\section{Introduction}

The use of plant extracts in the treatment of various diseases in humans has existed for decades, and the research is ongoing. Different parts of plants such as the leaves, stem, barks, roots, etc. are being used to prevent, alleviate symptoms or revert abnormalities in humans. Although these traditional therapies have been ongoing for a long time, the dangers, including cases of burns and intoxications have been observed from extracts containing very toxic and harmful substances. Nevertheless, these natural and traditional practices or therapies are in rising demands due to the ever-increasing and challenging health crisis in the world, especially in developing countries. In order to combat the numerous phenomena of bacterial resistance in humans and animals, new therapeutic agents must be produced from plants. They are at the center of multiple

*Corresponding author: Coulibaly Wacothon Karime Email address: wacothon@yahoo.fr

DOI: http://dx.doi.org/10.13171/mjc10702007241441cwk studies for their use in the treatment of several pathologies ${ }^{1,2}$. M. scaber Zucc (Rubiaceae) is being used in traditional medicine to treat certain skin diseases such as eczema ${ }^{3}$ and ringworm ${ }^{4}$. Despite its use in traditional medicine, very few scientific studies have been conducted on this species, hence the importance of new research on the various organs (roots, stems, leaves, and seeds) of this plant. Therefore, the objective of this study is to determine the phytochemical and antioxidant properties of M. scaber in the extracts of the leaves, stem, roots, and seeds. The present work is done to contribute to the valorization of medicinal plants used in the Ivory Coast.

\section{Experimental}

2.1. Materials and methods

2.1.1. Materials

Received April 9, 2020

Accepted May 27, 2020

Published July 24, 2020 


\subsubsection{Plant material}

The leaves, stems, roots, and seeds of M. Scaber were collected in July 2017 at Nangui Abrogoua University (Ivory Coast). They were identified by Dr. DJAH Malan Jean-Francois, Professorresearcher, in Botany at the said University. These parts were washed twice with tap water, were dried for one month and three days. They were then pulverized through an artisanal mill.

\subsubsection{Technical material}

Technical equipment used: a precision balance (Denver, S-234 series, Max 230g), a Buchner, a UV lamp (254 and $366 \mathrm{~nm})$, a spectrophotometer (AL8000Aquatic series), a rotary evaporator of HEIDOLPH1 type and an electric dryer. The deposits on thin-layer chromatography (TLC) were carried out on chromatographic plates bought in the starts (silica gel 60 F254, aluminum, $20 \times 20 \mathrm{~cm}$, Merck).

\subsubsection{Experimentation}

\subsubsection{Extraction of secondary metabolites 2.1.2.1.1. Maceration}

Each powdered plant material $(5.00 \mathrm{~g})$ was macerated in $50.00 \mathrm{~mL}$ of methanol $(80 \%)$ with constant stirring for 24 hours. The extract was obtained through suction filtration and stored between $4-5^{\circ} \mathrm{C}$ in a refrigerator. This operation was repeated twice, keeping the same pomace, but with a fresh solvent. Hydromethanol macerates were combined in different flasks and then concentrated under reduced pressure at $50^{\circ} \mathrm{C}$ with a rotary evaporator to give four crude hydromethanol extracts (leaves, stem, roots, and seeds) from $M$. scaber. After concentration, the resulting hydromethanol crude extracts were dried in an oven and then weighed using a precision balance (Denver, S-234 series, Max $230 \mathrm{~g}$ ) for the calculation of the yield. These extracts were subsequently used to prepare selective extracts and carry out the different assays.

\subsubsection{Preparation of selective extracts}

Extracts from the leaves, stems, roots, and seeds were respectively treated with the following increasing polarity solvents: hexane, chloroform, ethyl acetate, and n-butanol. The crude hydromethanol extract $(20.00 \mathrm{~mL})$ was successively extracted with $3 \times 10 \mathrm{~mL}$ of hexane, chloroform, ethyl acetate, and n-butanol. The different fractions obtained (hexane, chloroform, ethyl acetate, nbutanol) were concentrated on a rotary evaporator at $50^{\circ} \mathrm{C}$ and then stored in a refrigerator $\left(4-5^{\circ} \mathrm{C}\right)$ for subsequent use in phytochemical screening and antioxidant activity.

\subsubsection{Phytochemical screening of selective extracts}

The different extracts obtained from hexane, chloroform, ethyl acetate, and n-butanol were identified and analyzed using Thin Layer Chromatography (TLC) ${ }^{5-7}$.

\subsubsection{Determination of total polyphenols}

Total polyphenol content was determined using the colorimetric method proposed by Folin-Ciocalteu and used by other authors ${ }^{8-11}$. $1.00 \mathrm{~mL}$ solution of each extract was diluted to $1 / 20$ with distilled water. $1.50 \mathrm{~mL}$ of $\mathrm{Na}_{2} \mathrm{CO}_{3}(17 \%, \mathrm{w} / \mathrm{v})$ and $0.50 \mathrm{~mL}$ of Folin-Ciocalteu reagent $(0.5 \mathrm{~N})$ was added to the resulting solution. The absorbances were determined at $720 \mathrm{~nm}$ using a spectrophotometer. The total phenolic content was also determined using a standard made up of different concentrations of gallic acid $(y=0.0083 x+0.0147)$.

\subsubsection{Determination of total flavonoids}

Total flavonoid assay was performed using the method proposed by Hariri et al., (1991) ${ }^{12}$ and used by Kabran ${ }^{8}$. In this method, $2 \mathrm{~mL}$ of each hydromethanol extract was diluted to $1 / 20$ with distilled water and mixed with $100 \mu \mathrm{L}$ of Neu reagent. The absorbance was read at $404 \mathrm{~nm}$, and the result compared to that of quercetol taken as standard $(0.05 \mathrm{mg} / \mathrm{mL})$, diluted under the same conditions, and treated with the same amount of reagent. The percentage of total flavonoids was calculated in quercetol equivalent according to the following formula below proposed by Hariri et al., (1991) ${ }^{12}$.

$$
F(\%)=\frac{\frac{0.05 \times A e x t \times 100 \times d}{A q}}{\text { Cext }}
$$

Where; $\mathrm{F}(\%)=$ percentage of total flavonoids; Aext $=$ Absorbance of the extract; $\mathrm{Aq}=$ Absorbance of quercetol; $\mathrm{d}=$ dilution; Cext $=$ Concentration of extract $(\mathrm{mg} / \mathrm{mL})$

\subsubsection{2,2-diphenyl-1-picrylhydrazyl (DPPH) radical scavenging activity}

The antioxidant activity of the extracts was carried out using the spectrophotometric method proposed by Popovici et al. ${ }^{13}$ and repeated by N'Gaman, (2013) ${ }^{11}$. The (2,2-diphenyl-1-picrylhydrazyl) $\mathrm{DPPH}^{*}$ was dissolved in absolute ethanol to obtain a concentration of $0.02 \mathrm{mg} / \mathrm{mL}$. Similarly, solutions of the extract were prepared in absolute ethanol with varying concentrations $(0.25 \mathrm{mg} / \mathrm{mL}, 0.50 \mathrm{mg} / \mathrm{mL}$, $1.00 \mathrm{mg} / \mathrm{mL}, \quad 1.50 \mathrm{mg} / \mathrm{mL}, 2.00 \mathrm{mg} / \mathrm{mL}$ and $3.00 \mathrm{mg} / \mathrm{mL}$ ). In a dry and sterilized test tube, $0.50 \mathrm{~mL}$ of the different extract concentrations was mixed with $1.50 \mathrm{~mL}$ of the solution of DPPH at 30 minutes interval. The resulting mixture was thoroughly mixed and placed in the dark for 15 minutes. The absorbance of the mixture was measured using a spectrophotometer $517 \mathrm{~nm}$ (maximum wavelength of $\mathrm{DPPH}^{\circ}$ ). The absorbance was measured at 3 minutes' interval for 15 minutes. This process was repeated for the different extract solutions. Ascorbic acid (vitamin C) was used as a reference for positive control. The scavenging effect was calculated as:

$\% I=\left(A_{0}-A_{1}\right) \times 100 / A_{0}$ 
Where $\mathbf{A}_{0}=$ absorbance of the control; $\mathbf{A}_{1}=$ absorbance of the extract.

A standardized graph of the extract concentration versus the scavenging activity was plotted to extrapolate the concentration efficiency of the plant extract at $50 \%$ reduction of DPPH $\left(\mathrm{IC}_{50}\right)^{8}$.

\section{Results and discussion}

\subsection{Phytochemical Screening}

\subsubsection{Hexane extract}

In this method, family-specific reagents were used to determine large families of secondary metabolites. Steroids were determined using the Godin's reagent. This was seen as purple or brown spots in the visible region ${ }^{8}$. According to Lagnika (2005) ${ }^{14}$ and Kabran (2014) ${ }^{8}$, sterols are identified using the Libermann-
Burchard reagent as brown and green spots in the visible region, and yellow and yellow-green spots in the UV region at $366 \mathrm{~nm}$. Similarly, terpenes are identified as blue and purple spots in the visible region. Reports from Ogunleye et al. also confirmed these results., (2019) ${ }^{15}$ with ethanol extract of M. scaber leaves.

In addition, solutions of methanol containing $5 \%$ $\mathrm{KOH}$ were used to determine coumarins. It was observed that only extracts from the roots confirm the presence of coumarins seen as a blue spot $\left(\mathrm{R}_{\mathrm{f}}=0.53\right)$ in the UV region at $366 \mathrm{~nm}$, as approved by Ladiguina et al. ${ }^{16}$. The other plant extracts (seeds, stems, and leaves) do no show the presence of coumarins, but they contain sterols and terpenes, as shown in Table 1.

Table 1. Phytochemical constituents of hexane extract of leaves, stems, roots, and seeds of M. scaber.

\begin{tabular}{|c|c|c|c|c|}
\hline Secondary metabolites & leaves & stems & roots & seeds \\
\hline Sterols and terpenes & + & + & + & + \\
\hline Coumarins & - & - & + & - \\
\hline
\end{tabular}

$(+)=$ presence; $(-)=$ absence

\subsubsection{Chloroform extracts}

Specific reagents were used to identify the different large families of secondary metabolites.

Dragendorff reagent was used to determine the presence of alkaloids in the extracts. After treating the different extracts of chloroform with Dragendorff reagent, no spot was observed on the chromatographic plate, indicating the absence of alkaloids. In addition, the Neu reagents, in combination with $\mathrm{AlCl}_{3}$, were used to determine the presence of flavonoids in the different plant extracts.
Our results indicate the presence of flavonoids in all the plant extracts (leaves, stem, roots, and seeds) observed as blue spots on the chromatographic plates with $R_{\mathrm{f}}$ values of 0.71 and 0.63 . These results are in agreement with previous reports by Ogunleye et al. ${ }^{15}$. This also confirms the presence of flavones and isoflavones, as previously reported 11,14,17-21. Similarly, the different plant extracts (leaves, stem, roots, and seeds) obtained from methanol in $5 \%$ $\mathrm{KOH}$ reveal the presence of coumarins with $\mathrm{Rf}$ value of 0.76 . The results are summarized in Table 2 .

Table 2. Phytochemical constituents of chloroform extracts of leaves, stem, roots, and seeds of M. scaber.

\begin{tabular}{|c|c|c|c|c|}
\hline Secondary metabolites & leaves & stems & roots & seeds \\
\hline Coumarins & + & + & + & + \\
\hline Flavonoids & + & + & + & + \\
\hline Alkaloids & - & - & - & - \\
\hline
\end{tabular}

$(+)=$ presence; $(-)=$ absence

\subsubsection{Ethyl acetate extracts}

To determine organic compounds present in the extract from ethyl acetate, 3:0.2 (v/v) AcOEt/AcOH solvent mixture was used as the extracting solvent. The results show the presence of flavonoids in all the extracts and no alkaloids even after using Dragendorff reagent, which is specific to alkaloids (Table 3) ${ }^{14}$. This result is contrary to previous reports from Ogunleye et al. ${ }^{15}$.

Table 3. Phytochemical constituents of ethyl acetate extract of leaves, stem, roots, and seeds of M. scaber.

\begin{tabular}{|c|c|c|c|c|}
\hline Secondary metabolites & leaves & stems & roots & seeds \\
\hline Flavonoids & + & + & + & + \\
\hline Alkaloids & - & - & - & - \\
\hline
\end{tabular}

$(+)=$ presence; $(-)=$ absence 


\subsection{4. n-butanol extracts}

The EtOAc/EtOH/AcOH/ $/ \mathrm{H}_{2} \mathrm{O}$ solvent system in the ratio 4: 0.6: 0.5: $0.5 \mathrm{v} / \mathrm{v} / \mathrm{v} / \mathrm{v}$ was used to analyze the extracts prepared from n-butanol. After carrying out the phytochemical screening on the extracts, results reveal the presence of tannins, polyphenols, flavonoids, and coumarins in all the extracts (Table 4). Summarily, TLC analysis on the extracts prepared from hexane, chloroform, ethyl acetate, and n-butanol, reveal the presence of sterols, terpenes, coumarins, flavonoids, tannins, and polyphenols.

Table 4. Phytochemical constituents of n-butanol extracts of leaves, stem, roots, and seeds of M. scaber.

\begin{tabular}{|c|c|c|c|c|}
\hline Secondary metabolites & leaves & stems & roots & seeds \\
\hline Coumarins & + & + & + & + \\
\hline Flavonoids & + & + & + & + \\
\hline Tannins and polyphenols & + & + & + & + \\
\hline
\end{tabular}

$(+)=$ presence; $(-)=$ absence

\subsection{Total polyphenol content}

Results of the total polyphenol content in the plant extracts using hydromethanol as extracting solvent are presented in Figure 1.

From the results, the total polyphenol content in the crude extracts of $M$. scaber indicated that all the extracts (leaves, roots, seed, and stem) contain polyphenols ranging from 174.059 to 488.291 $\pm 1.205 \mu \mathrm{g} \mathrm{GAE} / \mathrm{g}$ of the dry matter. The leave extracts of $M$. Scaber contain the highest amount of polyphenols $(488.291 \pm 1.205 \mu \mathrm{g} \mathrm{GAE} / \mathrm{g})$, followed by extracts from the seeds $(344.277 \pm 0.696 \mu \mathrm{g}$
$\mathrm{GAE} / \mathrm{g})$ and then the stems $(237.538 \pm 1.205 \mu \mathrm{g}$ $\mathrm{GAE} / \mathrm{g}$ ), with the roots containing the least amounts of polyphenols $(174.059 \pm 1.840 \mu \mathrm{g} \mathrm{GAE} / \mathrm{g})$. These results are significant and consistent with a previous study carried out with Butanol-HCl ${ }^{17,22,23}$. Besides, these reports have confirmed that polyphenols possess numerous pharmacological and biological properties, including their use as antioxidants, antibacterial, anti-inflammatory agents, etc. Derivatives of polyphenols such as tannins and flavonoids have been used as antioxidants to fight against certain body disorders caused by oxidative stress ${ }^{24-26}$.

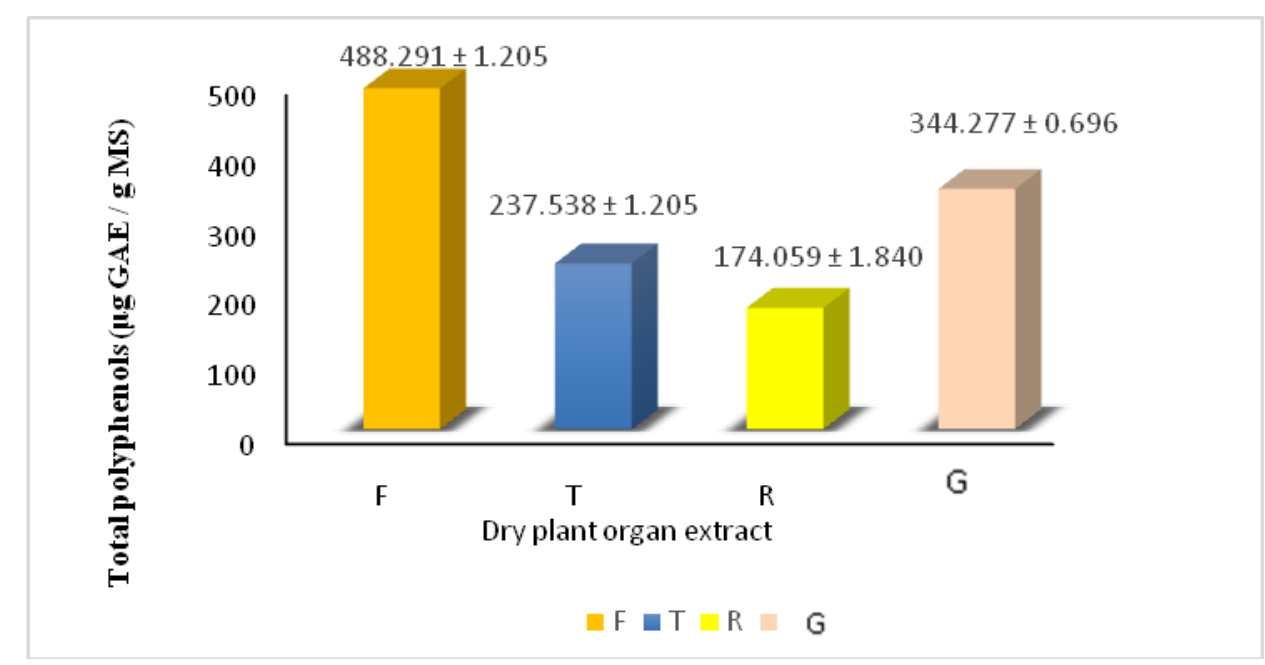

Figure 1. Total polyphenols content in different plant extracts of $M$. scaber $\mathrm{F}=$ leaves, $\mathrm{T}=$ stem, $\mathrm{R}=$ root, $\mathrm{G}=$ seeds

\subsection{Total flavonoid content}

Total flavonoid contents in the extracts of leaves, stems, roots, and seeds of $M$. scaber with methanol used as the extracting solvent are presented in Figure 2. Similarly, flavonoids are unevenly distributed in $M$. scaber plant with percentages ranging from $0.6166 \pm 0.0001 \%-1.6236 \pm 0.0317$ $\%)$. The highest flavonoids content are found in the leaves $(1.6236 \pm 0.0317 \%)$, followed by the seeds
$(1.3780 \pm 0.0248 \%)$, the stem $(0.7812 \pm 0.0135 \%)$, with the roots having the least amounts of flavonoids $(0.6166 \pm 0.0001 \%)$. These results are in agreement with earlier results from Kambo et al., (1999) ${ }^{27}$.

The increased flavonoid content in the leaves and seeds can be attributed to their exposure to sunlight compared to other parts of the plant ${ }^{10,11}$. 


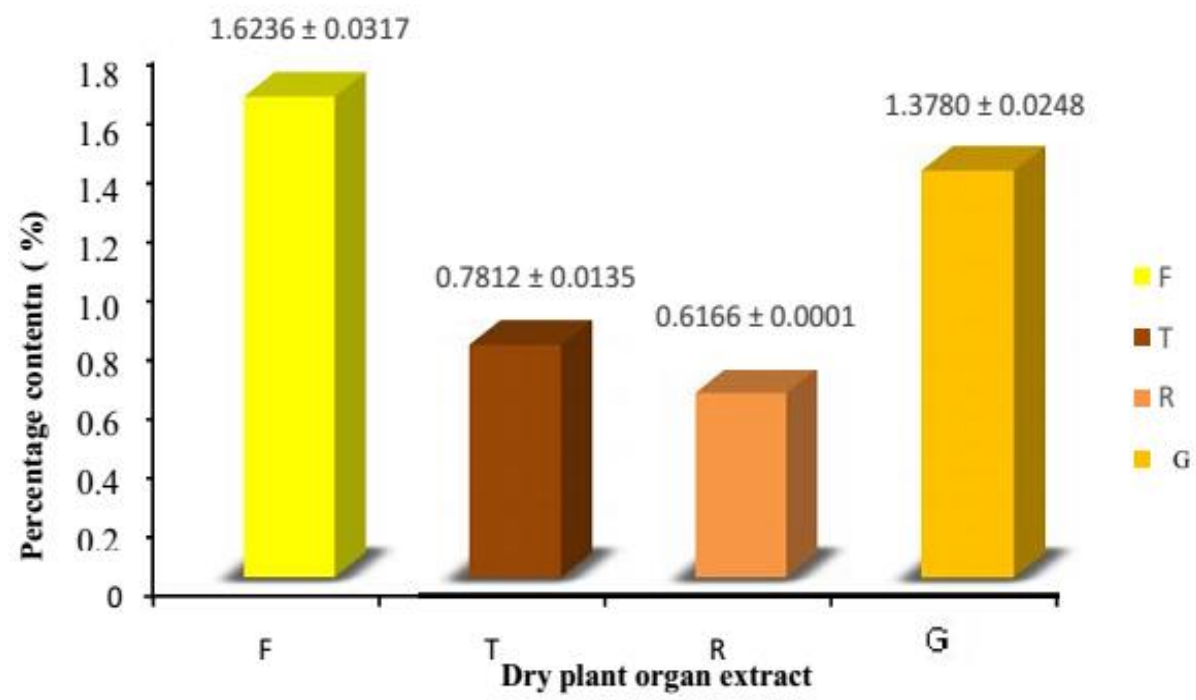

Figure 2. Total flavonoids content of different parts of $M$. scaber F: Leaves; T: Stem; R: Roots and G: Seeds

\subsection{2,2-diphenyl-1-picrylhydrazyl (DPPH) radical} scavenging activity of n-butanol extracts

Figure 3 represents the inhibition of the various extracts with n-butanol in relation to the behavior of $\mathrm{DPPH}^{\bullet}$. These extracts were incubated at 3 minutes interval for 15 minutes. The different methods used are the FRAP method, the ORAC, and the radical $\mathrm{DPPH}^{\bullet}$ method ${ }^{28}$. The preference for the radical scavenging DPPH ${ }^{\bullet}$ method in the determination of antioxidant activity in compounds or extracts is due to its simplicity and ease of use, its speed, and the formation of a stable radical ${ }^{29}$. The antioxidant properties of the extracts were determined with reference to ascorbic acid (vitamin C), which is considered a natural oxidant. The results revealed that all the extracts exhibited anti-radical effects as a function of time. An increase or a decrease in the percentage of inhibition was observed every 3 minutes. Similarly, the rate of inhibition also varies as a function of time. This trend was also observed in ascorbic acid (vitamin C), which is the reference molecule with a radical-activity value of $96.617 \%$. In the n-butanol extracts, the radical scavenging activity was $90.57 \%$ and $83.67 \%$ in the leaves and seeds, respectively. These results are in agreement with those obtained by TLC. From Figure 3, it is seen that the antioxidant activity in the extracts is similar to those observed in vitamin C. In general, results of anti-radical activity using the spectrophotometer were in agreement with the assays of total polyphenols and total flavonoids ${ }^{28}$. In addition, our study revealed the behavior of DPPH on our hydromethanol extracts as a function of time.

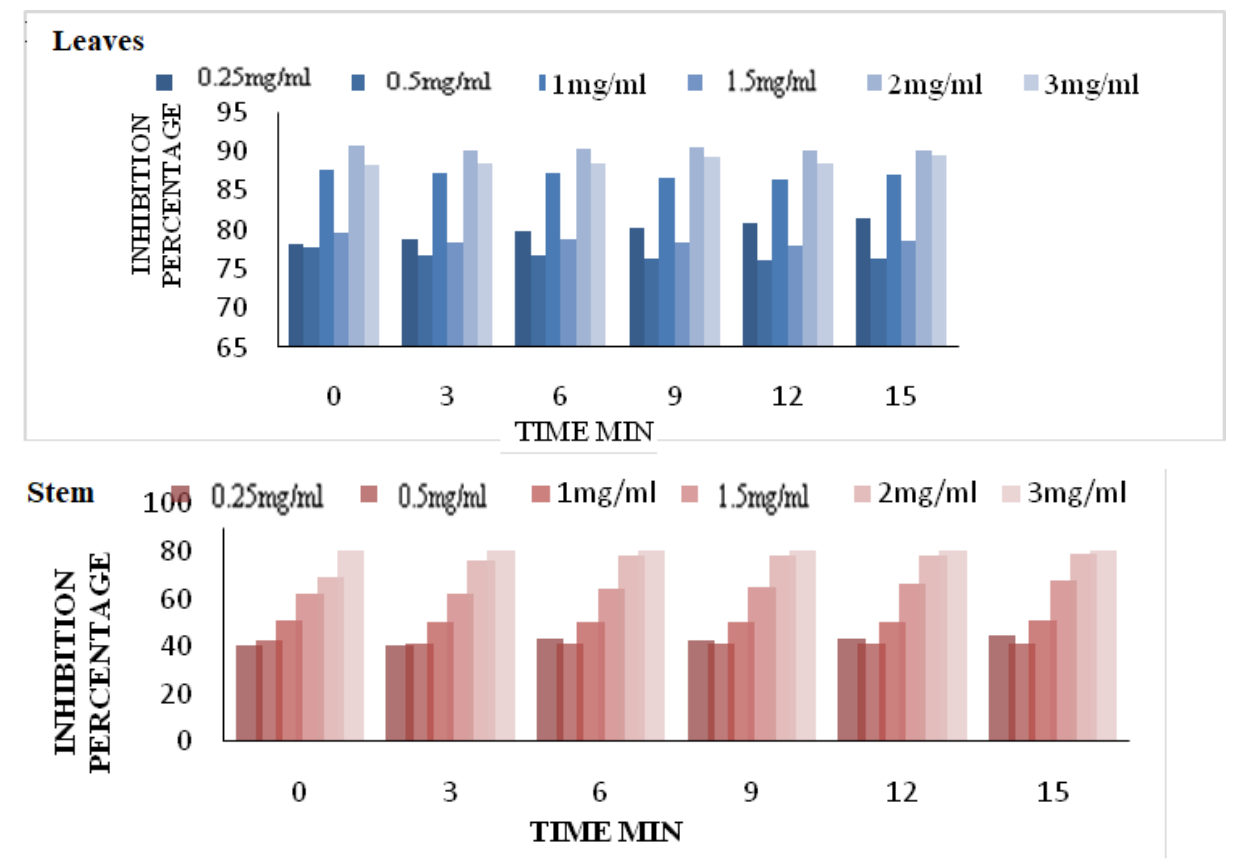




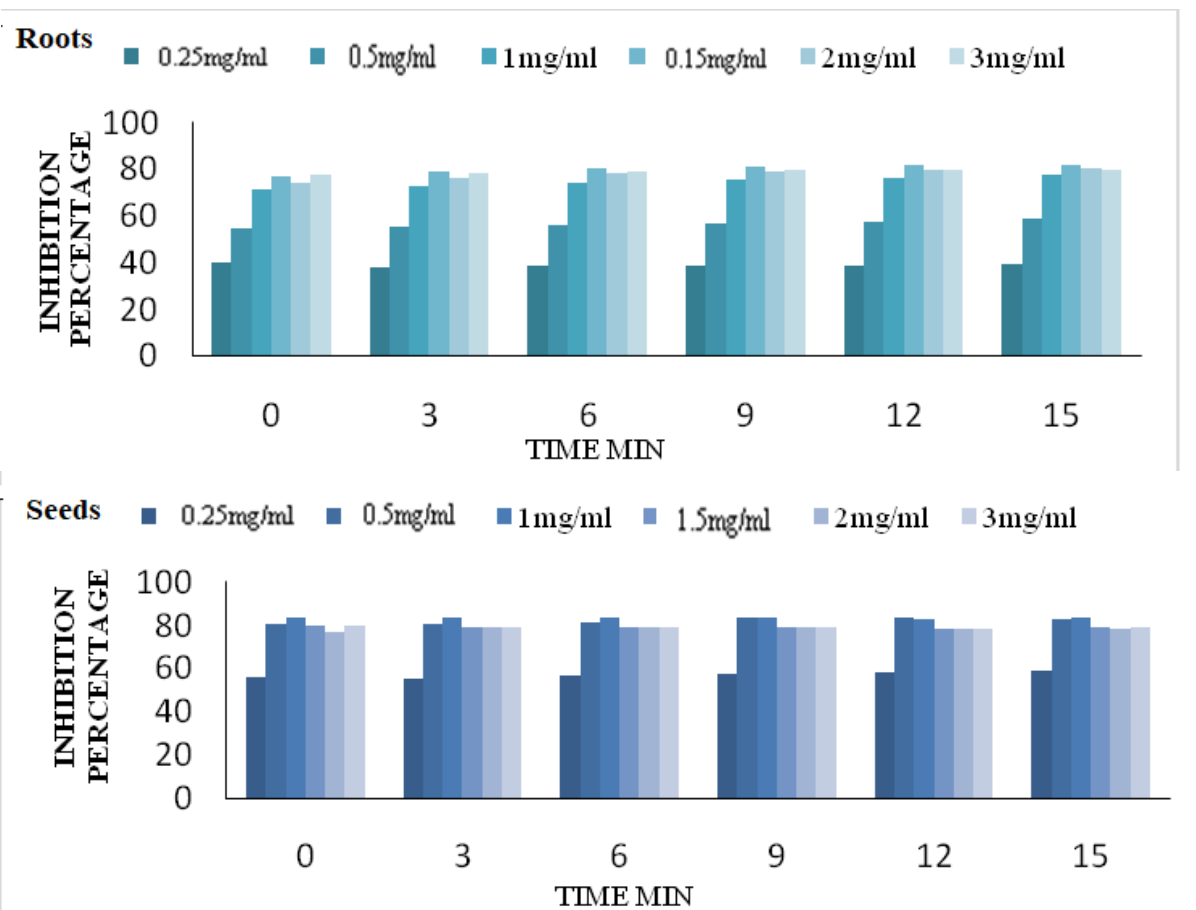

Figure 3. DPPH radical scavenging activity of n-butanol extracts of leaves, stem, roots, and seeds of $M$. scaber

\subsubsection{Determination of inhibition concentrations (IC50)}

The inhibition concentration $\left(\mathrm{IC}_{50}\right)$ is defined as the concentration of a compound at $50 \%$ efficacy in inhibiting a biological function. The effectiveness of a compound in inhibiting a biological function is inversely related to its $\mathrm{IC}_{50}$. The lower the $\mathrm{IC}_{50}$ of a compound, the higher its ability to inhibit a biological function and vice versa ${ }^{30}$. The antioxidant activity of the extracts was determined from the $\mathrm{IC}_{50}$ in comparison to the standard (vitamin C). The efficient concentration of the plant extract to which
$50 \%$ of the DPPH has been reduced $\left(\mathrm{IC}_{50}\right)$ was determined graphically from the graph of the standardized extract concentration versus the scavenging activity.

The results obtained showed that the seed extracts prepared from n-butanol fraction exhibit the most crucial activity with an $\mathrm{IC}_{50}$ lower than that of ascorbic acid. This implies that flavonoids, which are abundant in the seeds, have the highest antioxidant activity ${ }^{31-33}$.

Table 5. $\mathrm{IC}_{50}$ values for n-butanol, ethyl acetate extracts, and vitamin $\mathrm{C}$.

\begin{tabular}{|c|c|c|c|c|c|}
\hline $\begin{array}{l}\text { Extracts Time } \\
(\mathrm{mg} / \mathrm{mL})\end{array}$ & 3 min & $6 \mathrm{~min}$ & $9 \mathrm{~min}$ & $12 \mathrm{~min}$ & $15 \mathrm{~min}$ \\
\hline n-butanol leaves & 1.21 & 1.23 & 1.79 & 1.76 & 1.85 \\
\hline n-butanol stem & 1.39 & 1.37 & 1.33 & 1.35 & 1.29 \\
\hline n-butanol roots & 0.79 & 0.73 & 0.76 & 0.72 & 0.99 \\
\hline n-butanol seeds & 0.27 & 0.25 & 0.24 & 0.23 & 0.29 \\
\hline AcOEt leaves & 1.59 & 1.77 & 1.73 & 1.81 & 1.45 \\
\hline AcOEt stem & 0.95 & 0.85 & 0.59 & 0.81 & 0.80 \\
\hline AcOEt roots & 0.79 & 0.76 & 0.72 & 0.73 & 0,99 \\
\hline AcOEt seeds & 0.49 & 0.48 & 0.47 & 0.48 & 0.39 \\
\hline Vit. C & 0.35 & 0.36 & 0.37 & 0.36 & 0.39 \\
\hline
\end{tabular}

\section{Conclusion}

The present study is, therefore, an essential contribution to the chemistry of Mitracarpus scarber Zucc. (Rubiaceae), to understand the effects of the use of this plant in the treatment of certain diseases in the Ivory Coast.

The phytochemical and antioxidant activities of different parts of the plant were successfully analyzed, M. scaber. Hexane, chloroform, ethyl 
acetate and n-butanol extracts of the plant leaves, stem, roots, and seeds contain flavonoids, coumarins, tannins, sterols, polyphenols, and terpenes. Our results show high amounts of polyphenols and flavonoids in the leaves and seeds of the plant. The total flavonoid assay revealed a high content in the leaves $(1.624 \pm 0.032 \%)$. This can be attributed to their frequent exposure to sunlight compared to the other parts of the plant. Our comparative studies indicate an uneven distribution of secondary metabolites in the different parts of the plant-with secondary metabolites being absent in some parts. Besides, the studies of the antioxidant activities by $\mathrm{DPPH}^{\bullet}$ (2,2-diphenyl-1'-picrylhydrazyl) method showed a significant effect compared to vitamin $\mathrm{C}$ (96.62 \%). The percentages of inhibition are respectively $89.82 \%$ and $82.3 \%$ for ethyl acetate extracts of the leaves and seeds. The DPPH spectrophotometric tests revealed that the leaves and seeds of the plant with higher contents in polyphenols and flavonoids also have good antioxidant activity.

In several serious diseases, notably, those linked to aging, oxidative stress is the primary triggering factor. Since the n-butanol extract has shown good antioxidant activity by the DPPH method, it would be essential for us to confirm the antioxidant activity by performing other methods such as the Frap and Abts methods. The use of this plant could help us in the prevention of certain diseases linked to oxidative stress. Subsequently, we will perform biological antifungal and antibacterial tests to confirm the traditional use of the plant.

\section{Acknowledgments}

The authors are grateful to Prof. Attioua Koffi Barthelemy of Laboratoire de Chimie Organique et de Substances Naturelles, UFR Sciences des Structures de la Matière et Technologie, Université Félix Houphouët-Boigny, Abidjan, Côte d'Ivoire, for phytochemical studies.

\section{References}

1- K. H. Baser, G. Tümen, N. Tabanca, F. Demirci, Composition and antibacterial activity of the essential oils from Satureja wiedemanniana (Lallem.). Velen. Z., Natur for sch., 2001, 56, 731-738.

2- J.K. Chalchat, L.P. Carry, C. Menut, G. Lamaty, R. Malhuret, J. Chopineau, Correlation between chemical composition and antimicrobial activity. VI. Activity of some African essential oils, J. Essent. Oil Res., 1997, 9, 67-75.

3- E.J. Adjanohoun, La médecine traditionnelle au Bénin : recensement des savoir- faire traditionnels, Méd. Pharm. Afri., 2001, 15, 103-111.

4- T.O. Ekpendu, P.A. Akah, A.A. Adesomoju, J.I. Okogun, Antiinflammatory and antimicrobial activities of Mitracarpus scaber extracts, International Journal of Pharmacognosy, 1994, 32, 991-2196.

5- Y-A. Békro, J. Y-A. Mamyrbekova-Békro, B.B. Boua, F. Tra Bi, E. Ehilé, Etude ethnobotaniqueet screening phytochimique de Caesalpinia benthamiana (Baill.) Herend. et Zarucchi (Caesalpiniaceae), Sciences et Nature, 2007, 4, 217-225.

6- J. Y-A. Mamyrbékova-Békro, M. Konan, Y.A. Békro, M. Djié Bi, T. Zomi Bi, V. Mambo, B.B. Boua, Phytocompounds of the extracts of four medicinal plants of Côte d'Ivoire and assessment of their potential antioxidant by thin-layer chromatography, European Journal of Scientific Research, 2008, 24, 219-228.

7- K.C.C. N'gaman, Y-A. Békro, J. Mamyrbékova-Békro, A. Bénié, B.S. Gooré, Sur la composition en métabolites secondaires et l'activité anti-oxydante d'extraits bruts de GmelinaarboreaRoxb. (Verbanaceae) de Côte d'Ivoire, Afrique de l'Ouest : Analyse par Chromatographie sur Couche Mince, European Journal of Scientific Research, 2009, 36, 161-171.

8- G. R. M. Kabran, N. C. Ambeu, J. A. Mamyrbékova-Békro, Y-A. Békro, Total Phenols and Flavonoids in Organic Extracts of Ten Plants used in Traditional Therapy of Breast Cancer in Côte d'Ivoire, European Journal of Scientific Research, 2012, 68, 182-190.

9- A. B. KADJA, J. A. Mamyrbékova-Békro, A. Benie, Erythrophleum africanum Afzel. (Caesalpiniaceae), an African toothpick: Phytochemical screening, total flavonoid content and antioxidant activity, Journal of Medicinal Plants Research, 2011, 5(27), 6273-6277.

10- A-H. O. N'Guessan, C. E. Dago, J. A. Mamyrbékova-Békro, Y-A. Békro, Teneurs en composés phénoliques de 10 plantes médicinales employées dans la tradithérapie de l'hypertension artérielle, une pathologie émergente en Côte d'Ivoire, Revue de Génie Industriel, 2011, 6, 55-61.

11- C. C. N'gaman, G. R. M. Kabran, B. A. Kadja, J. A. Mamyrbékova-Békro, J. L. Pirat, M. Lecouvey, O. Sainte-Cathérine, N. Sommerer, A. Verbaere, E. Meudec, Y. A. Békro, ULPCMS/MS phenolic quantification and in vitro anticancer potential of Gmelina arborea Roxb. (Verbenaceae), Der Chemica Sinica, 2014, 5(6), 13-17.

12- E. B. Hariri, G. Sallé, C. Andary, Involvement of flavonoids in theresistance of two poplar cultivars to mistletoe (Viscum album L.). Protoplasma, 1991, 16, 20-26.

13- C. Popovici, I. Saykova, B. Tylkowski, Evaluation de l'activité antioxydante des composés phénoliques par la réactivité avec le 
radical libre DPPH, Revue de génie industriel, 2009, 4, 25-39.

14- B. Wenigera, L. Lagnika, C. VonthronSénécheau, T. Adjobimey, J. Gbenou, M. Moudachirou, R. Brun, R. Anton, A. Sanni, Evaluation of ethnobotanically selected Benin medicinal plants for their in vitro antiplasmodial activity, Journal of Ethnopharmacology, 2004, 90, 279-284.

15- A.O. Ogunleye, O.D. Florence, M.T. Hassan, Phytochemical and antimicrobial activity of the ethanol leaf extract of Mitracarpus scaber, FUDMA Journal of Sciences (FJS), 2019, 3, $1-2$.

16- E.Y. Ladiguina, L.N. Safronitch, V.E. Otriachenkova, I.A. Balandina, N.I. Grinkevitch, Analyse chimique des plantes médicinales. Edition Moskva, VischayaChkola, 1983, 347 p. (Translated from Russian).

17- K. M. Konan, J. A. Mamyrbékova-Békro, Y.A Békro, Quantification of total phenols and flavonoids of Desmodium adscendens (Sw.) DC. (Papillionaceae) and projection of their antioxidant capacity, J. Appl. Biosci. 2012, 49, 3355- 3362.

18- N. Ali, M. Moudachirou, J.A. Akakpo, J. Quetin-Leclercq. Treatment of bovine dermatophilosis with Cennaalata, Lantana camara et Mitracarpus scaber, J. Ethnopharmacol, 2003, 86, 167-171.

19- Mohammedi Z., F. Atik, Antioxidant Activity of Four Algerian Plants: Cistus ladaniferus, Crataegus oxyacantha, Lavandula stoechas and Smyrnium olusatrum, Asian Journal of Chemistry, 2011, 23(2), 709-712.

20- K.R. Markham, Techniques of flavonoid identification. Biological techniques Series. EditionTreherne J. E., Rubery P. H. Academic press., 1982, 113p.

21- B.P. Georgivskii, N.F. Komissarenko, Dmitrour C.E. (1990). Les composés bioactifs des plantes médicinales, édition Naouka. 336 p (traduit du Russe).

22- B. Ouadja, K. Anani, B. Djori, Y.O. Amoyapoh, D.S. Karou, Evaluation of the phytochemical composition, antimicrobial and anti-radical activities of Mitracarpus Scaber (Rubiaceae), J. Med. Plants Res., 2018, 12(28), 493-499.

23- H. Falleh, R. Ksouri, C. Abdelly, Activité antioxydante et contenu en polyphenols dans les différents organes de l'artichaut sauvage, Cynaracardunculus, Revue des Régions Arides, numéro spécial SIPAM, 2006, 26, 341-344.

24- O.M.P. Sharma, T.K. Bhat, (2009). DPPH antioxidant assay revisited. Food Chemistry, 113, $1202 \mathrm{p}$.
25- R. Amarowicz, Tannins: the new natural antioxidants? Eur. J. Lipid. Sci. Technol., 2007, 109, 549-451.

26- H. Falleh, R. Ksouri, K. Chaieb, B. Karray, N. Trabelsi, M. oulaaba, et al., Phenolic composition of Cynara cardunculus L. organs, and their biological activities, CR Biol., 2008, pp. 331-372.

27- a) K. E. Kporou, A. K. M. Kra, S. Ouattara, F. Guede-Guina, J. Djaman-Allico, Improvement by chromatographic dividing of anticandidosic activity of an hexanic extract Mitracarpus scaber on the in vitro growth of Candida albicans and Candida tropicalis, Phytothérapie, 2000, 8(5), 290-294.

b) N. A. Emmanuel, M. Moudachirou, A.J. Akakpo, J. Quetin-Leclercq, Activités antibactériennes in vitro de Cassia alata, Lantana camara et Mitracarpus scaber sur Dermatophilus congolensis isolé au Bénin, Revue Elev. Méd. Vet. Pays tropical, 2002, 55(3), 183-187.

28- I. Tagnaout, H. Zerkani, S. Amine, K. Fadili, N. Benhlima, A. Bouzoubaa, T. Zair. Phenolic composition and antioxidant potential of different solvent extracts of the endemic Origanum elongatum (Bonnet) Emberger \& Maire, Mediterranean Journal of Chemistry 2020, 10(2), 146-154.

29- B. Bozin, N. Mimica-dukic, I. Smojlik, A. Goran, R. Igic, Phenolics as antioxidants in garlic (Allium sativum L., Alliaceae, food chemistry), 2008, 111, 925-929.

30- H. Dellaoui, A. Berroukche, N. Halla, L. Boudaoud, M. Terras, Phytochemical study and evaluation of the antioxidant of Myrtus communis L. Fruit's Methanol extract, PhytoChem and BioSub Journal, 2018, 12(2), 2170-1768.

31- I. Umadevi, M. Daniel, S. D. Sabnis, Chemotaxonomic studies on some members of Anardiaceae; In Proceedings of the Indian Academy of Sciences, Plant sciences, 1988, 98, 205-208.

32- A. Romani, P. Pinelli, N. Galardi, N. Mulinacci, M. Tattini, Identification and quantification of galloyl derivatives, flavonoid glycosides and anthocyanins in leaves of Pistacialentiscus L., Phytochemical Analysis, 2002, 13, 79-86.

33- G. Chryssavgi, P. Vassiliki, M. Athanasios, T. Kibouri, K. Michael, Essential oil composition of Pistacialentiscus L. and Myrtuscommunis L. Evaluation of antioxidant capacity of methanolic extracts, Food Chemistry, 2008, 107, 1120-1130. 